\title{
COMMENTAAR NAAR AANLEIDING VAN: „DE ACCOUNTANT-ADMINISTRATIECONSULENT IN HET HANDBOEK ACCOUNTANCY"
}

\author{
door Prof. Drs. G. L. Groeneveld
}

Naar ik meen is het in het algemeen belang en in het belang van de beide ca. tegorieën accountants die bij de tweedeling binnen het accountantswezen in Nederland in het leven zijn geroepen, dat duidelijkheid bestaat over de functie van beide categorieën in het maatschappelijk verkeer. Naar mijn overtuiging is daar. toe vereist, dat de controlerende functie is voorbehouden aan de registeraccoun. tant. Daarin een eenzijdige uitleg te zien van alléén beperking van de bevoegd. heden van de accountant-administratieconsulent komt mij weinig rationeel voor.

Zoals ook uit mijn bijdrage in het Handboek Accountancy blijkt, bepleit ik in het belang van de accountant-administratieconsulent een eigen ontwikkeling van zijn stiel, naar eigen aard en karakter, en niet een ontwikkeling die leidt tot een beroepsuitoefening die een verkleinde uitgave zou zijn van die van de registerac. countant. Inderdaad neemt de accountant administratieconsulent die in de open. bare praktijkuitoefening werkzaam is, een onafhankelijke positie in, die door de wettelijke regeling, het tuchtrecht en de beroepsregelen met waarborgen is omgeven, zodat een hoge graad van betrouwbaarheid van zijn werk mag worden verondersteld. Daarom ben ik er van overtuigd, dat de accountant-administratieconsulent een belangrijke en uiterst nuttige functie op het terrein van administratie, advies en belastingen in het bedrijfsleven zal vervullen. Naarmate de accountant-administratieconsulent zich daarvan beter bewust is en zich daarvoor wil inzetten, zal hij minder behoefte hebben zich te bewegen op een gebied waarvoor hij niet is opgeleid en geen verantwoordelijkheid kan dragen. 